AL IBTIDA: JURNAL PENDIDIKAN GURU MI (2019) Vol 6 (2): 244-255

DOI: http://dx.doi.org/ 10.24235/al.ibtida.snj.v6i2.5226

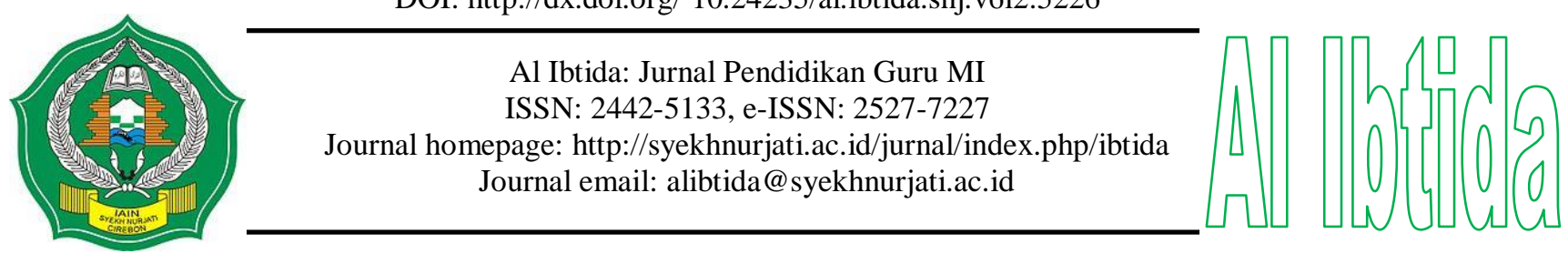

\title{
The Interaction Between Concrete-Pictorial-Abstract (CPA) Approach and Elementary Students' Self-Efficacy In Learning Mathematics
}

\author{
Aan Yuliyanto* \\ *Primary Education Study Program, School of Postgraduate, Universitas Pendidikan Indonesia \\ Email: aanyuliyanto@upi.edu \\ Turmudi** \\ **Department of Mathematics Education, Faculty of Mathematics and Natural Science, \\ Universitas Pendidikan Indonesia \\ Email: turmudi@upi.edu \\ Mubiar Agustin*** \\ ***Department of Early Childhood Teacher Education, Faculty of Educational Science, \\ Universitas Pendidikan Indonesia \\ Email: mubiar@upi.edu \\ Hafiziani Eka Putri***** \\ ****Department of Primary School Teacher Education, \\ Universitas Pendidikan Indonesia in Purwakarta \\ Email: hafizianiekaputri@upi.edu \\ Idat Muqodas***** \\ ******Department of Early Childhood Teacher Education, \\ Universitas Pendidikan Indonesia in Purwakarta \\ Email: idatmuqodas@upi.edu
}

Received: October $05^{\text {th }}, 2019$. Accepted: October $12^{\text {th }}, 2019$. Published: October $29^{\text {th }}, 2019$.

\begin{abstract}
Driven by the elementary students' low self-efficacy (SE) in learning mathematics, this study aims to delve deeper into the interaction between learning based on Mathematical Prior Ability (MPA) and the improvement of students' SE after the implementation of Concrete-PictorialAbstract (CPA) approach. In total, 119 elementary school students from Purwakarta, Subang, Karawang dan Bekasi participated. Both tests and non-tests were used as the instruments of this study. Using a quasi-experimental design with a nonequivalent pretest-posttest control group, a two-way ANOVA was used as the technical analysis of the data. The research results revealed that the learning factors are higher than 0.05 i.e. (0.235), the significance of the MPA factor is smaller than 0.05 i.e. (0.030), and the significance of the interaction factor (Learning MPA) is higher than 0.05 i.e. (0.301). It can be concluded that there is an interaction between learning (CPA and conventional) based on MPA and the students' SE. Thus, the CPA approach can be used to enhance the students' SE so that they can learn with higher confidence.
\end{abstract}

Keywords: concrete pictorial abstract, self-efficacy, mathematical prior ability. 


\begin{abstract}
Abstrak
Dilatarbelakangi oleh rendahnya efikasi diri siswa sekolah dasar dalam pembelajaran matematika, penelitian ini bertujuan untuk menyelidiki lebih jauh interaksi antara pembelajaran berbasis Kemampuan Awal Matematis (KAM) dengan peningkatan efikasi diri siswa setelah implementasi pendekatan Concrete Pictorial Abstract (CPA). Secara keseluruhan, 119 siswa sekolah dasar yang berasal dari Purwakarta, Subang, Karawang, dan Bekasi turut berpartisipasi. Baik tes maupun nontes digunakan sebagai instrument pada penelitian ini. Dengan menggunakan desain penelitian kuasi eksperimen dengan nonequivalent pretest postest control group, ANOVA dua jalur digunakan sebagai teknik analisis data. Hasil penelitian menunjukkan bahwa faktor pembelajaran lebih besar dari 0,05 yaitu $(0,235)$, signifikansi faktor KAM lebih kecil dari 0,05 yaitu $(0,030)$ dan signifikansi faktor interaksi (Pembelajaran KAM) lebih besar dari 0,05 yaitu $(0,301)$. Dapat disimpulkan bahwa terdapat interaksi antara pembelajaran (CPA dan konvensional) berdasarkan KAM dan efikasi diri siswa. Dengan demikian, pendekatan CPA dapat dijadikan solusi dalam meningkatan efikasi diri siswa sehingga mereka dapat belajar dengan kepercayaan diri yang lebih tinggi.
\end{abstract}

Kata kunci: concrete pictorial abstract, efikasi diri, kemampuan awal matematis.

\title{
INTRODUCTION
}

Education has specific purposes and ideals, the Law of National Education System Chapter II Article 3 revealed: National Education aims to develop the potential of students to become human beings who have faith and devotion to God Almighty, good characters, health, knowledge, capability, creativity, independence, democratic citizenship, and responsibility (Hendriana, Rohaeti, \& Soemarmo, 2017). Some of the latest studies in the curriculum in Indonesia include the emergence of STEM, which stands for Science, Technology, Engineering, and Mathematics. A study that supports the development of science and technology realized the goal of education in mathematics. The purpose of learning Mathematics is given at every level of primary and secondary education, which enables students to use Mathematics as a way of reasoning (logical, analytical, systematic, critical, and creative thinking and collaboration) BSNP (Rusman, 2014). One of the four objectives of the Mathematics curriculum is related to attitude. It is stated in Permendiknas Number 22 year 2006 that students need to respect the use of Mathematics in life, have curiosity, concern, and interest in learning Mathematics, and possess tenacious and confidence in solving problems (Department of Educational Human Resources Development and Education Quality Assurance, 2011). The goals of Mathematics learning require students to have reasonable confidence in problemsolving or self-efficacy. Self-efficacy is people's belief in their ability to produce designated levels of performance that affect their life activities (Bandura, 1994). Self-efficacy is a model for academic success since it motivates students' behavior (especially perseverance) that leads to success (Jinks \& Lorsbach, 2003). Self-efficacy affects the choice of student activities. Students with low self-efficacy in learning can avoid many tasks, especially challenging ones, while students with high self-efficacy are motivated to do the task, and they are proven to be more diligent in doing the tasks than the low ones Schunk in Santrock (2009). 
Some researches reveal that self-efficacy influences the choice of action taken and the amount of effort when encountering difficulties and obstacles. Individuals who have high self-efficacy choose to make more effort and are not easily discouraged, but many teachers do not pay attention to the psychological factors of students associated with student learning processes (Putri \& Santosa, 2015). Another study concluded that the increase in self-efficacy of students who got generative learning was better than those who received conventional learning, but the increase was still low (Moma, 2014). Another study suggested that teachers are involved in improving self-efficacy as a way to improve student achievement, and the increase will be very useful with low achievers (Jinks \& Lorsbach, 2003). If the student's self-efficacy is ignored, Mathematics will always be considered as a difficult subject. Sriyanto in Husna, Siman, \& Seragih (n.d) emphasized that Mathematics is a frightening and challenging subject for most students.

Related to the problem aforementioned, researchers intend to overcome it by applying the CPA approach. The CPA approach has been proven to be capable to make students eager in learning as they enjoy the lesson (Putri, 2017). In addition, excitement in learning has been proven to have an amazing effect on student learning outcomes. Emotional intelligence has contributed significantly to the effectiveness of learning in addition to intellectual intelligence (Darmansyah, 2011). The CPA approach in the learning process creates concrete and pictorial processes approximately similar to students' real life. According to Piaget's learning theory, children ate the age of seven to eleven begins to think rationally which indicated that they have logical operations applied to concrete problems (Dahar, 2011). Based on these strengths, the CPA approach is considered capable of increasing student self-efficacy because CPA can create meaningful learning for students with concrete and pictorial processes. The purpose of this study was to analyze the interaction between learning (CPA and conventional) with MPA (Mathematical Prior Ability) on primary school students' achievement and self-efficacy improvement.

Concrete-Pictorial approach-abstract (CPA) is a new approach in Indonesia but has been popular in Singapore. Concrete-Pictorial-Abstract (CPA) learning approach is called as a Concrete-RepresentationalAbstract (CRA) approach or Concrete-Semi concrete-Abstract (CSA) approach (Putri, 2018). This approach is based on Bruner's ideas on understanding the full concept, students change experience into a world model in three different ways, namely enactive, iconic, and symbolic. He called these three ways the mode of representation in which information is stored and coded in memory (Lee \& Tan, 2014). CPA approach has three steps, namely, manipulating process or concrete, connecting the manipulation process or pictorial, and learning using symbols and numbers or abstract (Yuliyanto, Putri \& Rahayu, 2019). The pictorial step strengthens student understanding and serves as a way to connect the framework to the real world on abstract concepts. The abstract step is a concept that benefits students for Mathematics reinforcement (Putri, 2017). Students will easily follow the learning process because students are brought to reality, apply it with pictures, and transform into abstract mathematical concepts.

There are five steps in learning Mathematics using CPA. First, selecting concrete (manipulative) 
objects used to introduce a conceptual understanding of the material being learned by students. Second, guiding students to participate independently in the use of concrete objects by giving instructions. The next step is replacing the use of manipulative objects with pictures. Fourth, using strategies that can help students to remember the previous steps. This serves as a process of transition from the use of images to the use of numbers or symbols. Last, encouraging students to only use numbers or symbols in completing the given task Flores in Putri (2017). In conclusion, CPA is an approach through a concrete stage which is done by manipulating objects directly, drawing stage by applying the results of manipulation of objects directly in the form of images or visually, and the final symbolic stage is to change it in an abstract form as typical of mathematics itself.

CPA learning benefits most students and has proven to be very effective in helping students who have difficulties in learning Mathematics since it moves gradually from the actual objects through images to symbols, Jordan, Miller, and Marcer in Putri (2017). This is in accordance with Bruner's learning theory that learning Mathematics will be more successful if in the learning process students are allowed to manipulate objects with Mathematics learning media, such as teaching aids (Lestari and Yudhanegara, 2017).

This study tried to seek the relation between the CPA approach and students' self-efficacy. Selfefficacy is defined as the belief of people about their ability to produce designated work levels that affect their life activities (Bandura, 1994). Self-efficacy can affect how people feel, think, motivate themselves, and behave (Bandura, 1993). In line with Bandura (1993), Jinks \& Morgan (1999) stated that the social learning theory defines the perception of self-efficacy as self-confidence regarding the performance of specific tasks. Self-efficacy beliefs functioned as a set of determinants of human motivation, influence, and action (Bandura, 1989). Zubaedi (2017) added that self-efficacy is a belief in its ability to think, learn, choose, and make choices accordingly, and to the next level, and be able to master challenges and manage change. McCutcheom (2008) also conveyed that self-efficacy is the judgment we make about our potential to learn successfully and belief in our abilities. The higher the sense of efficacy, the greater the effort, persistence, and resilience (Pajares, 1996). The scales for perceived self-efficacy for self-regulated learning assess students' perceived capability to use a variety of self-regulated learning strategies (Zimmerman, Bandura \& Pons, 1992).

Self-efficacy beliefs provide the foundation for human motivation, well-being, and personal accomplishment. Many empirical studies Bandura's contention that self-efficacy beliefs touch virtually in every aspect of people's lives, namely, -self-debilitating, motivation, vulnerability to stress and depression, and the life choices they make (Sharma \& Nasa, 2014). The impact of personal self-efficacy on the nature and quality of life depends on the intended use. A person possessing high self-efficacy is generally more flexible in dealing with situations that require the ability to adapt without having to isolate themselves from the complexity of the problems that surround his life (Rahma, 2011). Individuals engage in a behavior, 
interpret the results of their actions, use these interpretations to create and develop beliefs about their capability to engage in subsequent behaviors in similar tasks and activities, and behave in concert with the beliefs created (Pajares, 2002).

Self-efficacy can be learned through four sources, namely mastery experience, vicarious experience, verbal persuasion, and emotional conditions (physical condition) (Bandura,1994). Regarding the sources of self-efficacy, people's trust in their abilities is developed in four ways. First, mastery experience, indicated by overcoming obstacles through persistent effort and learning how to manage failure. Second, vicarious experience, that can be acquired from seeing people to increase confidence, believing in ourselves, doing and self-improvement. Zimmerman (2000) explained that enactive experiences are the most influential source of efficacy belief, whereas vicarious influences depend on an observer's selfcomparison with as well as outcomes attained by a model. Third, verbal persuasion which has a limited impact on students' self-efficacy because outcomes are described, not directly witnessed, and thus depend on the credibility of the persuader. Finally, students base their self-efficacy judgments on their perceived physiological reactions, such as fatigue, stress, and other emotions that are often interpreted as indicators of physical incapability. Self-efficacy is assumed to be responsive to changes in personal context and outcomes, whether it is experienced directly, vicariously, verbally, or physiologically (Zimmerman, 2000).

People also depend on their physical and emotional states in assessing their self-efficacy. The Indicators of self-efficacy are confidence in one's own abilities, confidence in the ability to adapt and deal with problematic tasks, confidence in the ability to face challenges, confidence in the ability to complete specific tasks, and confidence to complete several different tasks (Lestari and Yudhanegara, 2017). The purpose of this study is to analyze the correlation between learning CPA and students' MPA on the achievement and improvement of students' SE.

\section{METHODS}

This type of research is a quasi-experimental study that the researcher chose is Nonequivalent Control Group Design. The experimental group and the control group were not chosen randomly. The study population was elementary school students in Purwakarta, Subang, Karawang, and Bekasi. The samples were four classes involving two state elementary schools in Karawang, West Java. The participants consisted of 59 experimental students and 60 control students. Students in the experimental group were taught using the CPA approach and the control group using conventional methods. The research instrument including a description test, attitude scale, observation, daily journal, interviews, and documentation. Based on the test results of the self-efficacy scale instrument, 24 statements can be used further for research. All statements have sufficient validity $(\mathrm{rxy}=0.54)$ and high reliability $(\mathrm{r} 11=0.70)$. The data analysis was performed by descriptive and inferential analysis. Besides, to find the correlation between the variables, two-way ANOVA tests were used. 


\section{RESULTS AND DISCUSSION}

Based on the test of the average difference between students taught by using CPA method and those who taught by using conventional methods revealed that students with CPA method acquired better achievement and self-efficacy improvement than students taught using conventional methods. Students' MPA data is derived from the test regarding the required material in the present study. MPA test is aimed at grouping the students based on their ability (students with high, medium, and low ability) and to observe the equality of the students' mathematical prior ability in the two groups i.e. the group of students receiving CPA learning and the group of students receiving conventional learning (Putri, 2019). To see whether there is an influence of interaction between learning and MPA on students' self-efficacy, a two-way ANOVA test and average line graph analysis are conducted. Two-way ANOVA test was carried out to determine the role of learning, MPA and the interaction between the two factors. A recapitulation of the two-way ANOVA test for students' self-efficacy based on learning is presented in table 1.

Table 1. Recapitulation of Two Way ANOVA Test between Learning Factors and MPA on Selfefficacy Achievement

\begin{tabular}{cllllll}
\hline $\begin{array}{c}\text { Two Way } \\
\text { ANOVA }\end{array}$ & \multicolumn{1}{c}{ Source } & R square & $\boldsymbol{d f}$ & $\begin{array}{c}\text { Average } \\
\text { squared }\end{array}$ & $\boldsymbol{F}$ & $\begin{array}{c}\text { p-value (sig. 2- } \\
\text { tailed) }\end{array}$ \\
\hline Achievements & Learning & 16,181 & 1 & 16,181 & 1,427 & 0,235 \\
& MPA & 82,265 & 2 & 41,133 & 3,629 & 0,030 \\
& Learning*MPA & 27.537 & 2 & 13,768 & 1,215 & 0,301 \\
\hline
\end{tabular}

Based on the ANOVA test, it appears that the significance value of the learning factor is 0.235 which was higher than 0.05 and the significance value of the MPA factor is smaller than 0.05 i.e, 0.030 and the significance value of the interaction factor (Learning*MPA) is greater than 0.05 which is 0.301 . Therefore, the conclusions of the data analysis are as followed.

a) Learning factors have no significant influence on the achievement of students' self-efficacy. CPA learning factors have little effect on students' self-efficacy compared to students using the conventional method.

b) Students' MPA factors influence students' self-efficacy achievement. There are significant differences in students' self-efficacy achievement in each MPA.c) There is an interaction between learning factors and MPA on students' self-efficacy achievement.

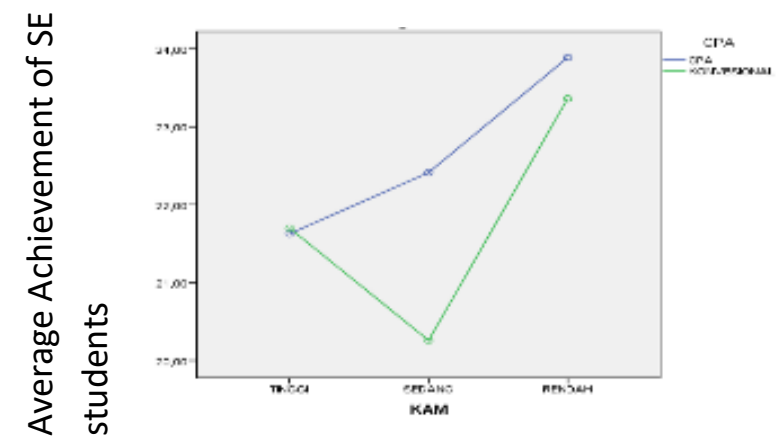

Figure 1. Interaction of MPA and Learning on the Students' Self-Efficacy Achievement 
Based on Figure 1, there is an interaction between MPA with learning of SE students. It can be concluded that the achievement of students' self-efficacy is not only influenced by the treatment but also the students' MPA. Next, we explain the interaction of MPA and learning with increasing SE with Figure. The data increase is not normally distributed.

Thus, to see whether there is an effect of interaction between learning and MPA groups on increasing students' self-efficacy can be done through the two-way ANOVA test and also average line graph analysis. The interaction of learning factors and MPA on increasing students' self-efficacy is presented in Figure 2.

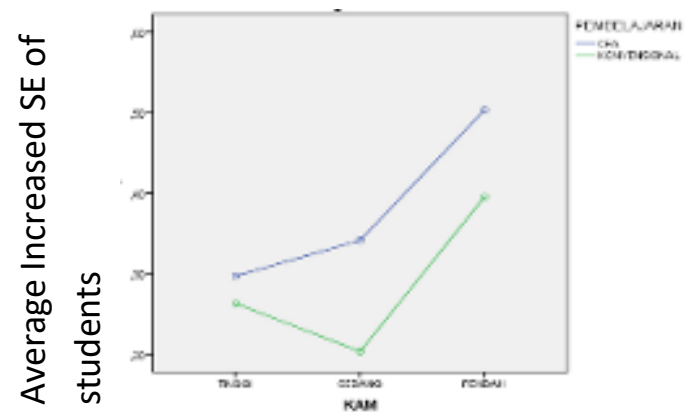

Figure 2. MPA Group Interaction and Learning to Increase Student SE

Based on Figure 2, there is no interaction between the group MPA and the learning to students' self-efficacy. It can be concluded that the increase in student SE is not influenced by student MPA. Some of the results of students' answers on the questionnaire distributed are displayed below.
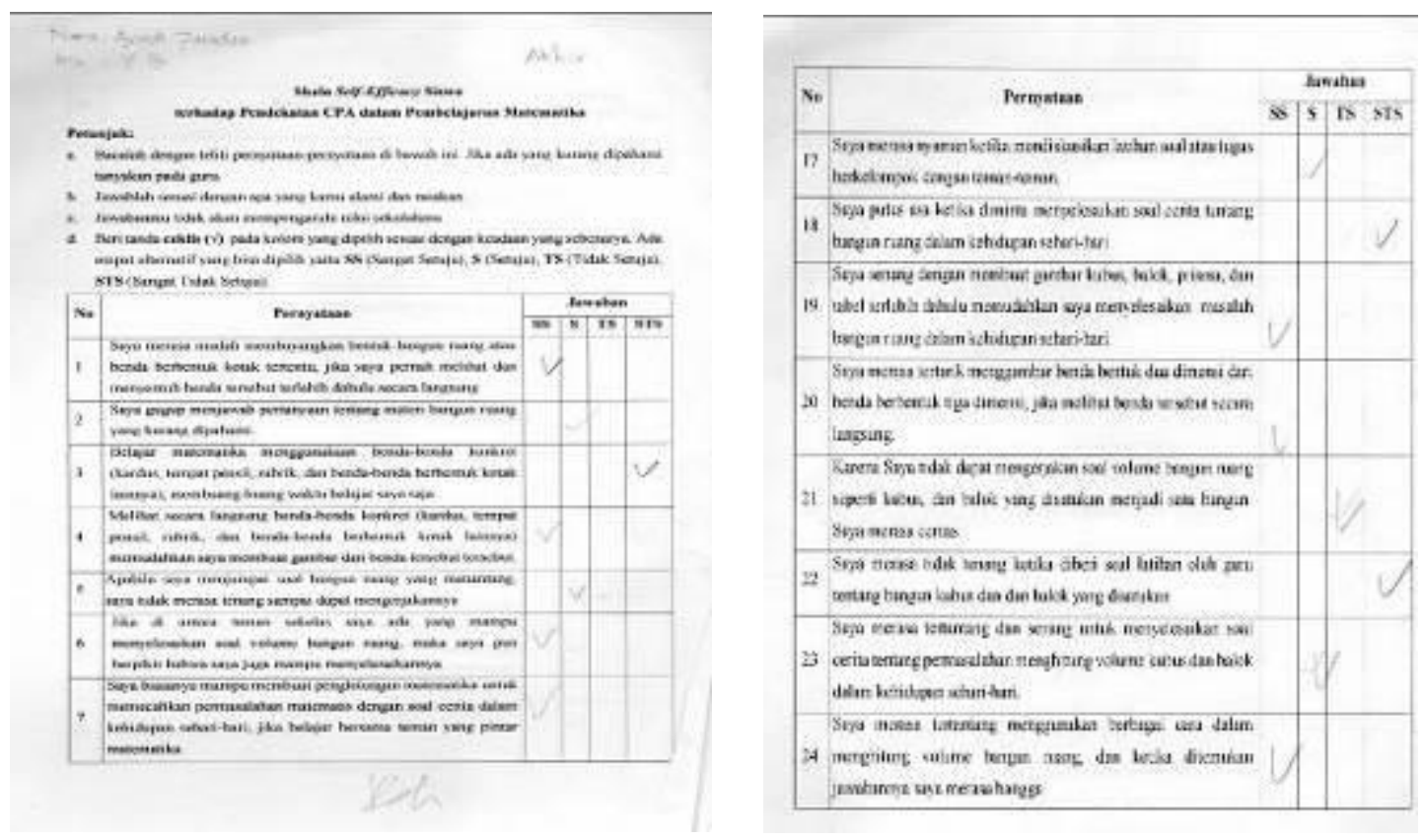


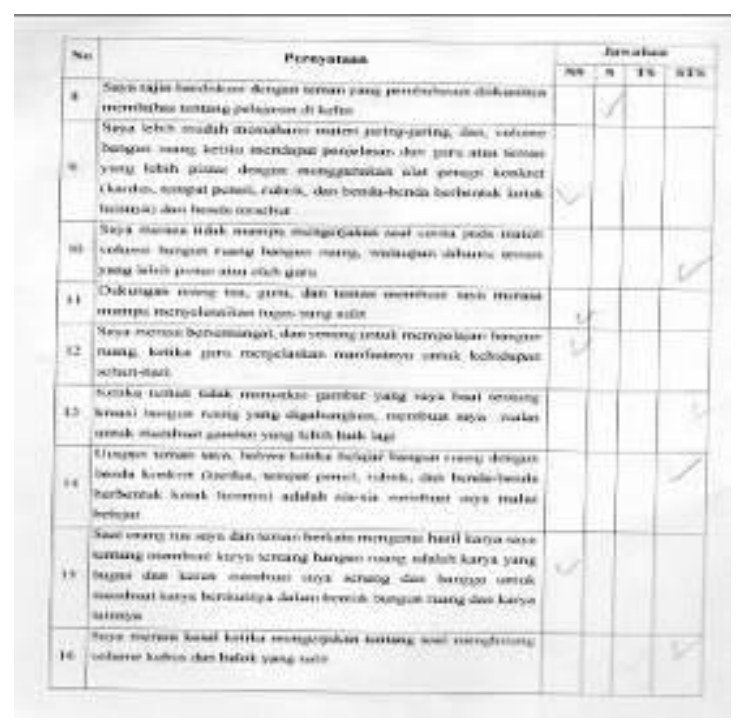

Figure 3. Self-efficacy Questionnaire results

Based on the result of students' questionnaire, students' confidence were varied and tentative. Sometimes, students strongly agree with statements that show they are confident, sometimes they agree and even disagree. There are 24 statements given to students, statements 1-5 represent personal experience aspect, statements 6-10 represent the experience of others aspect, statements 11-15 represent verbal persuasion aspect, and statements 16-24 represent psychological index aspect.

Learning using CPA is proved to increase achievement compared to learning using conventional methods except for indicators $2 \mathrm{c}, 4 \mathrm{~b}$, and $4 \mathrm{c}$. The highest achieved indicator was indicator $4 \mathrm{a}$, which is the belief to complete difficult tasks in good condition. The indicator also showed higher CPA learning compared to conventional learning. This is in accordance with Darmasyah (2011), who stated that students in delighted feelings would be able to increase their understanding and confidence. The lowest indicator achieved was experienced or indicator $2 \mathrm{a}$, which is the belief to complete a difficult task if others can complete it. This indicator also showed that CPA learning is higher than conventional learning. The full details are presented in the diagram below.

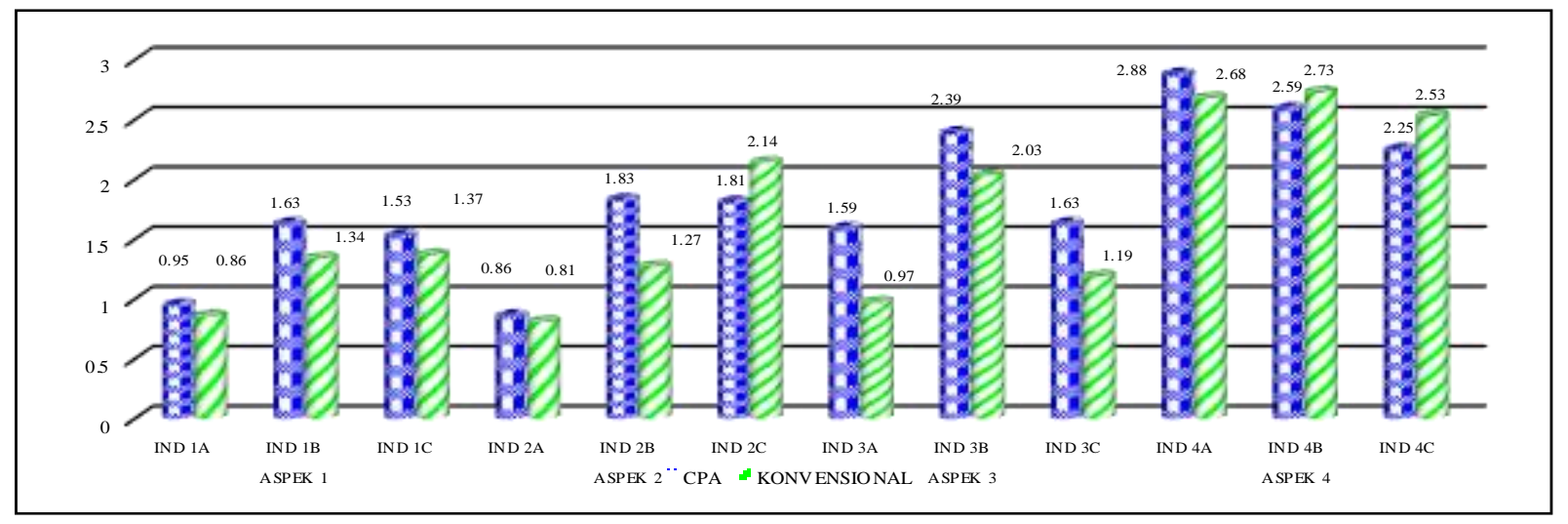

Figure 4. The average achievement of self-efficacy indicators 
The improvement of the indicators showed that the CPA approach could improve the student selfefficacy indicators compared to the conventional one. The highest increase in indicators occurred in the indicators that received CPA learning, 1c, which is confidence indicators to do challenging assignments. It was seen in the student journals where they felt challenged with questions that were in the moderate and demanding category. The lowest indicator to increase was indicator 1a in conventional learning, which is can complete a difficult task. The complete data are shown in the diagram below.

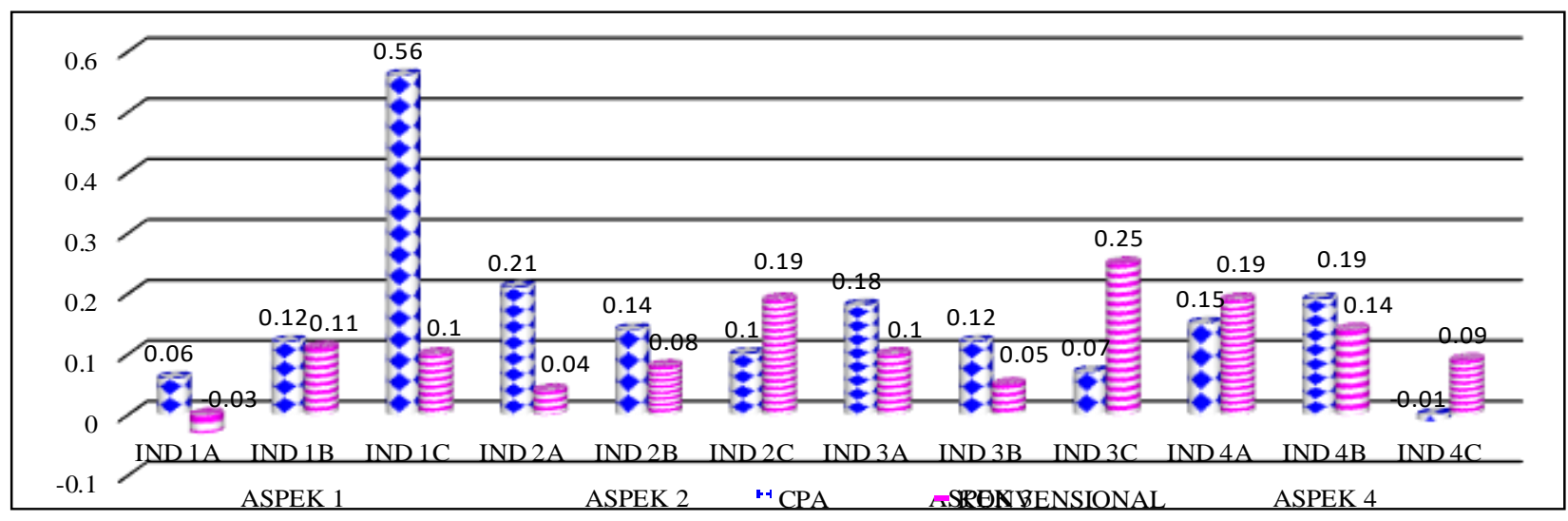

Figure 5. Average improvement in self-efficacy indicators

Based on the findings, there are some indicators achieved better using conventional methods than CPA. This is also in line with the result of interactions, where students' MPS influenced self-efficacy. Students with high MPAs are categorized to have high self-efficacy. Moma (2014) emphasized that there is no interaction between learning and school level on the increase of self-efficacy and soft skills.

Moreover, there is no interaction between MPA and learning to increase mathematical creative thinking abilities, self-efficacy, and soft skills. The result of the study is supported by a study conducted by Putri (2015), who found out that there was no interaction between learning factors and student MPA on the achievement and improvement of students' mathematical representation, spatial sense, and self-efficacy. Another study conducted by Fadri and Khafid (2018) showed that if self-efficacy and spiritual intelligence increase by one unit, then academic cheating will increase by 0.025 units. The study inferred that the interaction of self-efficacy and spiritual intelligence would strengthen the effect of self-efficacy on academic cheating. This study was similar to the previous one, which showed the interaction between the students' self-efficacy with MPA and learning. This indicated that students' SE results are not only influenced by CPA learning but also student's own MPA. On the contrary, the increase in the absence of interaction between students' SE with MPA and learning, this means that the increase in students' SE is purely influenced by CPA learning and not influenced by students' MPA. 


\section{CONCLUSION}

Based on the findings and discussion, it can be concluded that the achievement of self-efficacy can be seen as the interaction between MPA and learning. Therefore, the achievement of students' self-efficacy is not only influenced by the method implemented but is also influenced by students' MPA. The increase in self-efficacy is not affected by the interaction between MPA with Learning towards students' self-efficacy. Moreover, the increase in student self-efficacy is not influenced by students' MPA. Before implementing learning with CPA approach, there should be an arrangement of the learning plan to prepare the overall steps that must be implemented. In addition, before starting to learn, students need to understand the prerequisite material. This study is expected to contribute to the education development in Indonesia, especially in primary school, and to improve the knowledge and skills related to science. The findings of this study are also expected to be practically useful for teachers to develop students' attitude aspects.

\section{REFERENCES}

Badan Pengembangan Sumber Daya Manusia Pendidikan dan Penjaminan Mutu Pendidikan. (2011). Pengembangan Instrumen Penilaian Pembelajaran Matematika SD/SM. (E. Prajitno, Ed.) Jakarta: Kementerian Pendidikan Nasional.

Bandura, A. (1982). Self-Efficacy Mechanism in Human Agency. American Psychologist, 37(2), 122-147.

Bandura, A. (1989). Human Agency in Social Cognitive Theory. American Psychologist, 44, 1175-1184.

Bandura, A. (1993). Perceived Self-Efficacy in Cognitive Development and Functioning. Educational Psychologist, 28, 117-148.

Bandura, A. (1994). Self-Efficacy. (V. S. Ramachaudran, Ed.) Encyclopedia of Human Behavior, 4, 71-81.

Bandura, A. (1995). Self-efficacy in changing societies. Cambridge, England: Cambridge University Press.

Bandura, A. (2012). On the Functional Properties of Perceived Self-Efficacy Revisited. Journal of Management, 38(1), 9-44. DOI:10.1177/0149206311410606

Dahar, R. W. (2011). Teori - Teori Belajar \& Pembelajaran. Jakarta: Erlangga.

Darmansyah. (2011). Strategi Pembelajaran Menyenangkan dengan Humor. Jakarta: Bumi Aksara.

Fadri, N., \& Khafid, M. (2018). Peran Kecerdasan Spiritual Memoderasi Pengaruh Dimensi Fraud Diamond dan Self-efficacy terhadap Kecurangan Akademik. Economic Education Analysis Journal, 7(2), 430-448. Retrieved from http://journal.unnes.ac.id/sju/index.php/eeaj

Hendriana, H., Rohaeti, E. E., \& Sumarmo, U. (2017). Hard Skills dan Soft Skills Matematik Siswa. Bandung: Refika Aditama.

Husna, R., Siman, \& Seragih, S. (n.d.). Peningkatan Kemampuan Pemecahan Masalah dan Komunikasi Matematik melalui Pendekatan Matematika Realistik SMP Kelas VII Langsa. Jurnal Pendidikan Matematika PARADIKMA, 175-176.

Jinks, J., \& Lorsbach, A. (2003). Introduction: Motivation and Self Efficacy Belief. Reading \& Writing Quarterly: Overcoming, 19(2), 113-118. DOI:10.1080/10573560308218

Jinks, J., \& Morgan, V. (1999). Children's Perceived Academic Self-Efficacy: An Inventory Scale. The Clearing House: A Journal of Educational Strategies, Issues, and Ideas, 72(4), 224-230. doi:http://dx.doi.org/10.1080/00098659909599398 
Lee, N. H., \& Tan, B. J. (2014). The Role Of Virtual Manipulatives On The Concrete-Pictorial-Abstract Approach In Teaching Primary Mathematics. The Electronic Journal of Mathematics and Technology, 8, 102-121. doi:https://php.radford.edu/ ejmt/ContentIndex.php\#v1n2

Lestari, K. E., \& Yudhanegara, M. R. (2017). Penelitian Pendidikan Matematika. Bandung: PT Refika Aditama.

McCutcheom, S. L. (2008). Self-Efficacy in Mathematics: Affective, Cognitive, and Conative Domains of Functioning. Proceedings of the 31st Annual Conference of the Mathematics Education Research Group of Australasia, 507-513.

Moma, L. (2014). Peningkatan Kemampuan Berpikir Kreatif Matematis, Self-Efficacy dan Soft Skill Siswa SMP melalui Pembelajaran Generatif. Disertasi UPI: Tidak diterbitkan.

Pajares, F. (1996). Self-Efficacy Beliefs in Academic Settings. Review of Educational Research, 66(4), 543-578. DOI:10.3102/00346543066004543

Pajares, F. (2002). Gender and Perceived Self-Efficacy in Self-Regulated Learning. Theory Into Practice, $41(2), 116-125$.

Putri, H. E. (2015). The Influence of Concrete-Pictorial-Abstract (CPA) Approach to The Mathematical Representation Ability Achievement of The Pre-Teachers at Elementary School. International Journal of Education and Research, 3. Retrieved from www.ijern.com

Putri, H. E. (2017). Pendekatan Concrete-Pictorial-Abstract (CPA) Kemampuan-kemampuan Matematis \& Rancangan Pembelajarannya. (N. E. Suryani, \& R. Julianti, Eds.) Subang: Royyan Press.

Putri, H. E. (2019). Influence of concrete pictorial abstract approach to the improvement of spatial sense ability of elementary school students. International Conference on Mathematics and Science Education (ICMScE 2018) (pp. 1-7). Sumedang: IOP Publishing. DOI:10.1088/1742$6596 / 1157 / 4 / 042083$

Putri, H. E., Misnarti, \& Saptini, R. D. (2018). Influence of Concrete-Pictorial-Abstract (CPA) Approach towards The Enhancement of Mathematical Connection Ability of Elementary School Students. EduHumaniora: Jurnal Pendidikan Dasar, 10(2), 61-71.

Putri, R. I., \& Santosa, R. H. (2015). Keefektifan Strategi React ditinjau dari Prestasi Belajar, Kemampuan Penyelesaian Masalah, Koneksi Matematis, Self-Efficacy. Jurnal Riset Pendidikan Matematika, 2, 262-272. Retrieved from http://journal.uny.ac.id/index.php/jrpm/index

Rahma, A. N. (2011). Hubungan Efikasi Diri dan Dukungan Sosial Dengan Penyesuaian Diri Remaja di Panti Asuhan. PSIKOILSAMKA: Jurnal Psikologi Islam, 8(2), 231-246.

Riggs, I. M., \& Enochs, L. G. (1990). Toward the Development of an Elementary Teacher's Science Teaching Efficacy Belief Instrument. Science Education, 74(6), 625-637.

Rusman. (2014). Model-model Pembelajaran Mengembangkan Profesionalisme Guru (Kedua ed.). Jakarta: PT. RajaGrafindo Persada.

Santrock, J. W. (2009). Psikologi Pendidikan - Educational Psychology (Ketiga ed.). (D. Angelica, Trans.) Jakarta: Salemba Humanika.

Sharma, H. L., \& Nasa, G. (2014). Academic Self-Efficacy: A Reliable Predictor of Educational Performances. British Journal of Education, 2(3), 57-64.

Sugiyono. (2016). Metode Penelitian Kuantitatif, Kualitatif, dan R\&D. Bandung: Alfabeta.

Yuliyanto, A., Putri, H. E., \& Rahayu, P. (2019). Peningkatan Hasil Belajar Siswa SD melalui Pendekatan Concrete-Pictorial-Abstract (CPA). Metodik Didaktik, 14(2), 75-83.

Zimmerman, B. J. (2000). Self-Efficacy: An Essential Motive to Learn. Contemporary Educational Psychology, 25, 82-91. DOI:10.1006/ceps.1999.1016 
Aan Yuliyanto, Turmudi, Mubiar Agustin, Hafiziani Eka Putri, Idat Muqodas, The Interaction Between...

Zimmerman, B. J., Bandura, A., \& Pons, M. M. (1992). Self-Motivation for Academic Attainment: The Role of Self-Efficacy Beliefs and Personal Goal Setting. American Educational Research Journal, 29(3), 663-676. DOI:10.3102/00028312029003663

Zubaedi. (2017). Strategi Taktis Pendidikan Karakter Untuk PAUD dan Sekolah. Depok: Rajawali Pers. 